\title{
Rehabilitation of an adolescent patient's anophthalmic cavity with customized ocular prosthesis: a clinical report
}

\author{
Reabilitação de cavidade anoftálmica de paciente adolescente com prótese ocular customizada: \\ relato de caso
}

Rehabilitación de cavidad anoftalmica con prótesis ocular de una paciente adolescente: reporte de

\author{
Brenda Gonçalves de Carvalho \\ ORCID: https://orcid.org/0000-0002-8016-9599 \\ University of São Paulo, Brazil \\ E-mail: brenda gcarvalho@usp.br \\ Daniel Zuluaga Goyeneche \\ ORCID: https://orcid.org/0000-0002-4321-9147 \\ University of São Paulo, Brazil \\ E-mail: daniel-zuluaga@usp.br \\ Laís Ranieri Makrakis \\ ORCID: https://orcid.org/0000-0003-1831-5257 \\ University of São Paulo, Brazil \\ E-mail: lais.makrakis@usp.br \\ Cláudia Helena Lovato da Silva \\ ORCID: https://orcid.org/0000-0003-1629-2207 \\ University of São Paulo, Brazil \\ E-mail: chl@forp.usp.br
}

\begin{abstract}
The absence of an eyeball results in physical, psychosocial and functional alterations on an individual. Therefore, rehabilitation procedures are essential to repair the patient's self-esteem, self-confidence and physiological features. The aim of this study is to describe a case of ocular prosthetic rehabilitation in a pediatric patient. A female teenager, 17 years old, was referred to the maxillofacial prosthetic clinic to replace her former prosthesis fabricated two years ago. The new ocular prosthesis was confectioned with termopolymerizable acrylic resin and hand painted with acrylic paint on a colorless acrylic ocular bottom. The prosthesis was installed and the instructions were explained. In teenage patients the prothesis must be elaborated as soon as possible with periodic replacements in accordance with the growth period. The awareness of legal guardians and patients is essential to the success of the treatment in pediatric patients. In the present case, the patient was satisfied with the aesthetic and functional outcome.
\end{abstract}

Keywords: Artificial eye; Anoftalmos; Rehabilitation; Adolescent; Patient.

\section{Resumo}

A ausência do globo ocular resulta em alterações físicas, psicossociais e funcionais no indivíduo. Portanto, procedimentos reabilitadores são essenciais para reparar a autoestima, autoconfiança e características fisiológicas do paciente. O objetivo desse estudo é descrever um caso de reabilitação protética ocular em um paciente pediátrico. Uma adolescente, 17 anos de idade, foi referida à clínica de prótese maxilofacial para substituir sua prótese anterior fabricada há dois anos. A nova prótese ocular foi confeccionada com resina acrílica termopolimerizável e a íris foi pintada manualmente com tinta acrílica em uma calota acrílica incolor. A prótese foi instalada e as instruções foram explicadas. Em pacientes adolescentes, a prótese deve ser elaborada o quanto antes com trocas periódicas de acordo com o período de crescimento. A consciência dos responsáveis legais e pacientes é essencial para o sucesso do tratamento em pacientes pediátricos. No presente acaso, o paciente ficou satisfeito com o resultado estético e funcional.

Palavras-chave: Olho artificial; Anoftalmia; Reabilitação; Adolescente; Paciente.

\section{Resumen}

La ausencia del globo ocular afecta física, psicológica, social y funcionalmente un individuo. Por ese motivo, los tratamientos rehabilitadores son esenciales para devolver el autoestima, la autoconfianza y algunas características fisiológicas. El objetivo de este estudio es describir la rehabilitación de una paciente padiatrica con una prótesis ocular. La paciente femenina de 17 años de edad fue referida a la clínica de rehabilitación Maxilofacial para reemplazar su prótesis ocular entregada 2 años atrás. La nueva prótesis ocular fue confeccionada con resina acrílica termopolimerizable y pintada a mano con pintura acrílica en una calota trasparente. La prótesis fue instalada y la 
paciente recibió recomendaciones sobre limpieza y forma adecuada de uso. En pacientes pediatricos las prótesis oculares deben ser elaboradas lo más rápido posible con cambios periódicos de acuerdo con el crecimiento facial. La conciencia de los tutores legales y los pacientes es fundamental para el éxito del tratamiento en pacientes pediátricos. En este caso, la paciente quedó satisfecha con los resultados estéticos y funcionales de la prótesis.

Palabras clave: Ojo artificial; Anoftalmos; Rehabilitación; Adolescente; Paciente.

\section{Introduction}

The loss of an eye ball affects multiple areas of an individual's well-being related with the decrease of visual capacity, facial disfigurement, psychological stress and social rejection (Artopoulou, et al., 2006).

The main causes of eye removal are intraocular tumors and ocular trauma (Raizada, et al., 2011). Depending on the severity of the situation, the treatment approaches include different surgical procedures, such as enucleation, evisceration and exenteration of the eye. Enucleation consists on the removal of the entire globe and a portion of the optic nerve, but the muscles and orbital content remain intact. Evisceration involves removal of the intraocular contents of the globe leaving the sclera and the surrounding structures undisturbed. Exenteration is more invasive because it involves removal of the entire orbital contents including the muscles, nerves, eyelids, and the surrounding tissues within the orbit (Bartlett \& Moore, 1973; Jamayet, et al., 2013).

After the surgical procedures, it is important to go through a rehabilitation to recreate the appearance of a healthy eye and the surrounding tissues (Jain, et al., 2010). With the evolution of ophthalmic surgery and ocular prosthesis, replacement of an eye has become easier and more effective (Raizada, et al., 2011). The objectives of an ocular prosthesis are to maintain and protect the anophtalmic cavity, partially recover the lachrymal position, prevent the accumulation of lachrymal fluid in the eye cavity, recover facial aesthetics and enhance the self-esteem of the patient (Parr, et al., 1983; Fernandes, et al., 2009; Goato, et al., 2009).

Specifically, in pediatric and teenager patients, ocular prosthesis are important to prevent cosmetic deformities and facial asymmetries and to promote an adequate orbital growth preventing psychological problems (Kennedy, 1992). However, it is necessary to replace or modify the prosthesis within a period of 18 to 24 months in order to give continuous stimuli to the socket growth and follow the development of the surrounding tissues (Raizada, et al., 2011; Yago \& Furuta, 2001).

The aim of this study is to report a case of ocular prosthetic rehabilitations in a teenage patient.

\section{Methodology}

A 17-year-old teenager sought the service of the maxillofacial prosthetic clinic of School of Dentistry of Ribeirão Preto, University of São Paulo for the confection of a new custom-made ocular prosthesis on the left eye. The patient lost her eye due to a tumor when she was two-months-old and had received another prosthesis in the past. Her first ocular prosthesis was installed when she was 10 years old and then she changed that prosthesis when she was 12 years and another time when she was 14 years.

The patient's main complaint was related to an aesthetic inadequacy of the prosthesis she had used for two years. Clinical examination of the face indicated facial asymmetry and that prosthesis was not providing adequate eyelid support because of the growth that the patient presented throughout the years. Examination of the socket revealed healthy conjunctival lining and absence of infection (Figure 1). 
Figure 1. A) Frontal side of the patient. B) Anophthalmic cavity without prosthesis at the initial consult.

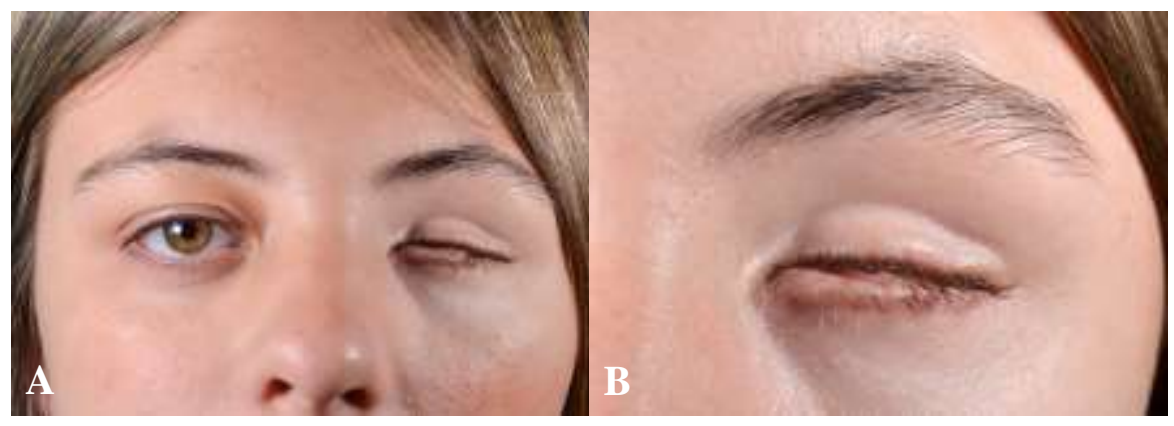

Source: Authors.

An impression of the anophthalmic socket was made with the injection of one portion of the condensation silicone (Perfil, Coltene, Rio de Janeiro, RJ, Brazil) with a syringe. The patient was instructed to stare at the front while the impression was taken (Figure 2).

Figure 2. Final impression of the anophathalimic socket A) Internal view B) External view.

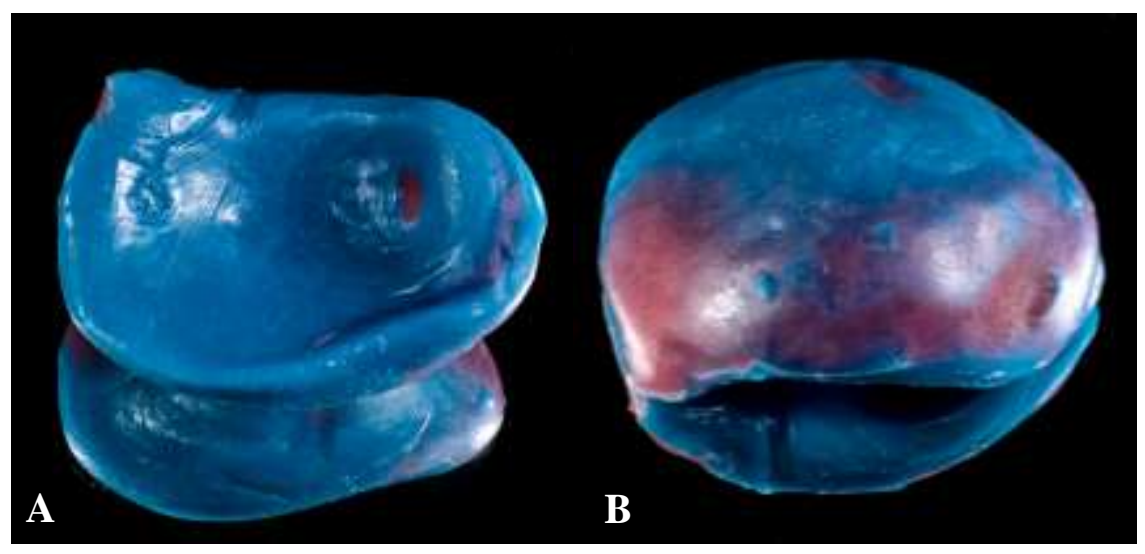

Source: Authors.

The impression was included in type III stone plaster (Gesso-Rio, Baumer, Mogi Mirim, SP, Brazil) in a metal muffle. After the crystallization, the mold was removed and a thermo-polymerizable resin color 66 (Vipicril Plus, VIPI, Pirassununga, SP, Brazil) was added and polymerized according to the manufacturer's recommendations. The resin pattern was finished and polished with brushes and pumice (Figure 3). 
Figure 3. Fabrication of the acrylic pattern. A) Inclusion of the impression in a metal muffle. B) Removal of the impression after crystallization of type III stone plaster. C) Addition of thermo-polymerizable resin. D) Compression of the acrylic resin on the flask. E) Acrylic pattern. F, G) Polishing and finishing. H, I) Finished acrylic pattern (internal and external view, respectively).

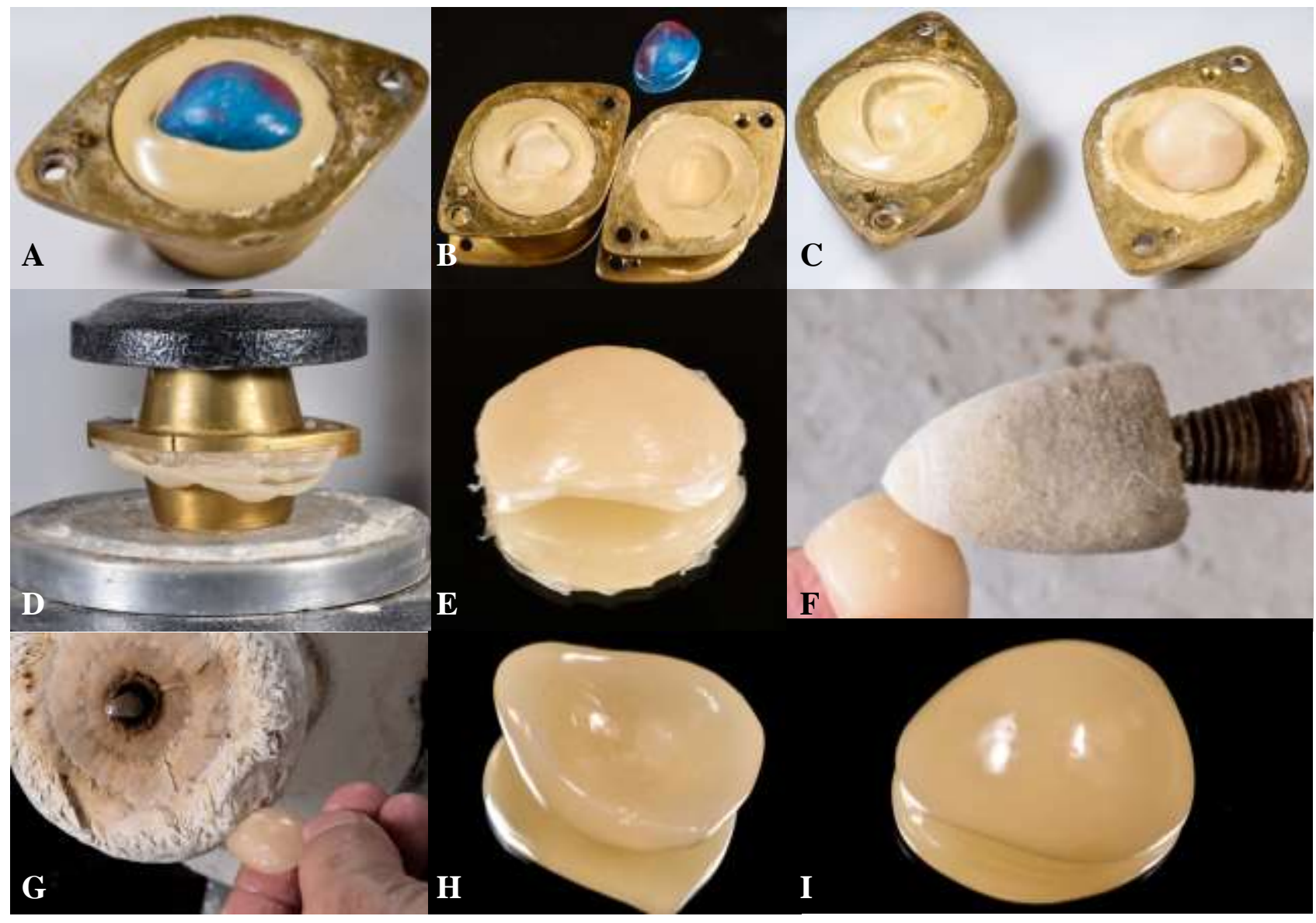

Source: Authors.

The acrylic sclera was evaluated on the patient's eye socket and its contours, convexity and lid movements were observed (Figure 4). The pattern's volume and superior contour were insufficient, so a layer of wax was added to the surface and superior margin of the sclera. After the volume recovery, contour adequacy and functionality of eyelid movements, a symmetrical point based on the pupil of the natural eye was marked on the acrylic sclera (Figure 5). 
Figure 4. Evaluation of the acrylic pattern on the patient's eye showing insufficient volume. A) Frontal side; B) Anophthalmic socket with the acrylic pattern.

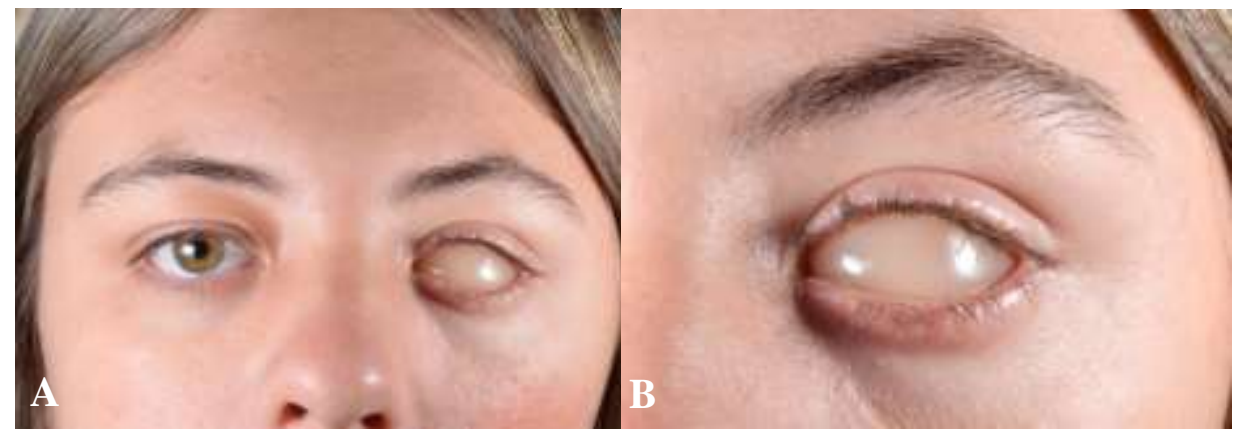

Source: Authors.

Figure 5. Wax addition on the acrylic pattern. A) Frontal side; B) Anophthalmic socket with the modified acrylic pattern; C, D) Modified acrylic pattern (internal and external view, respectively).

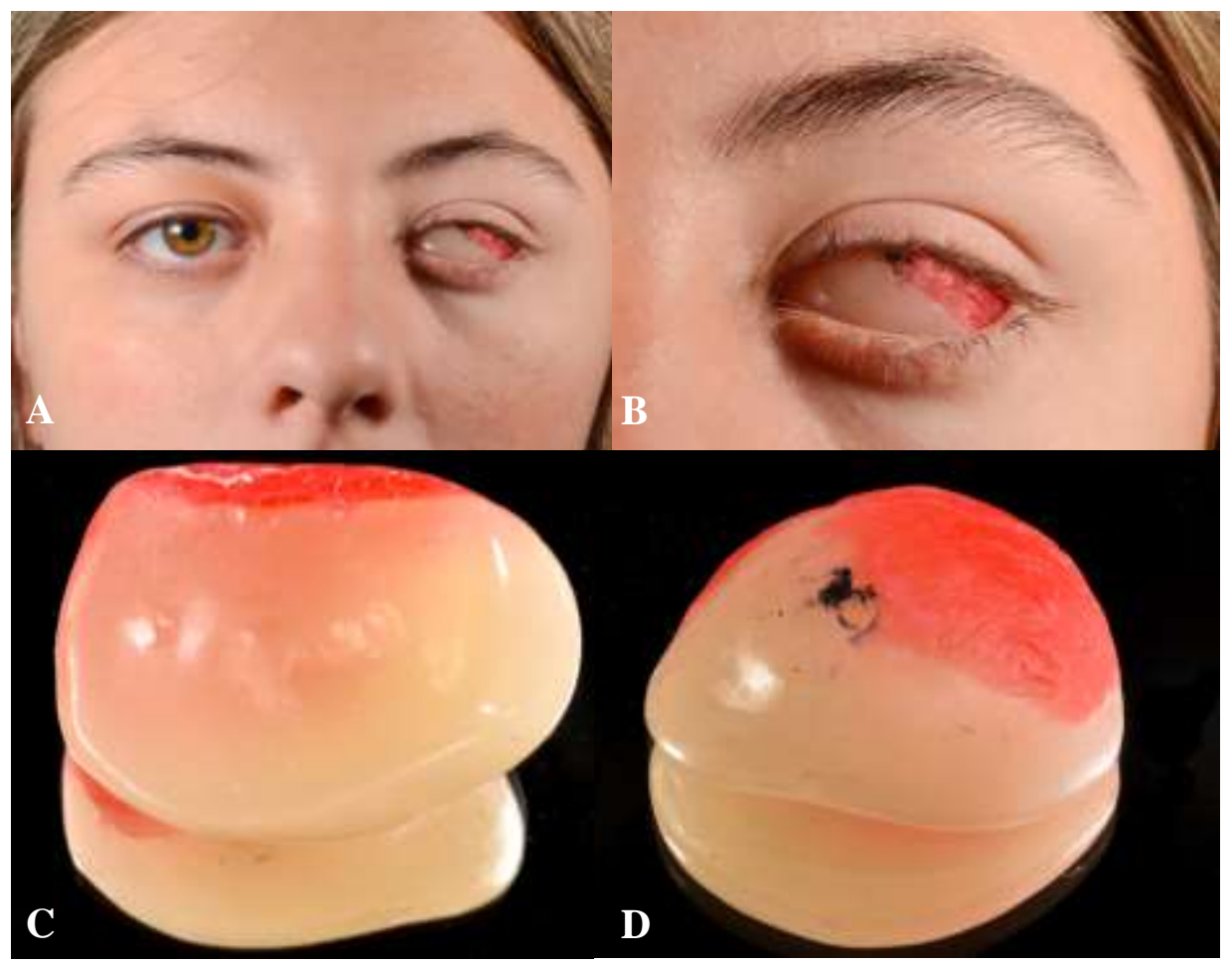

Source: Authors.

Then this modified pattern was included in type III stone plaster (Gesso-Rio, Baumer, Mogi Mirim, SP, Brazil) in a metal muffle. Subsequently a new sclera was manufactured again with thermo-polymerizable resin color N1 (Clássico Ltda., São Paulo, SP, Brazil). It was tried on the patient and considered satisfactory (Figure 6). 
Figure 6. Anophthalmic socket with the acrylic sclera.

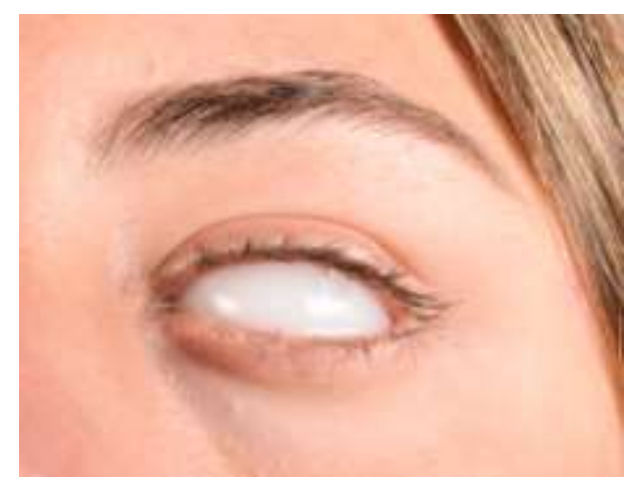

Source: Authors.

For the iris characterization, the iris of the right eye was measured and photos were taken to aid the painting of the prosthesis. A colorless acrylic ocular bottom was selected and reduced until it reached a diameter of $11 \mathrm{~mm}$. Then it was manually painted with a mix of acrylic paints (Figure 7). The iris was glued, with acrylic resin in the same color of the sclera. The acrylic resin that corresponds to the sclera was worn in 3-mm in its entire surface with one trunk-conical drill, preserving the margin of the iris and of the outer edge. Red silk fibers were adhered to the acrylic resin using a mixture of polymer and monomer (Classic, São Paulo, SP, Brazil) in a 1:10 ratio (more or less) to contribute to a natural appearance of veined sclera

Figure 7. Acrylic paints for iris characterization.

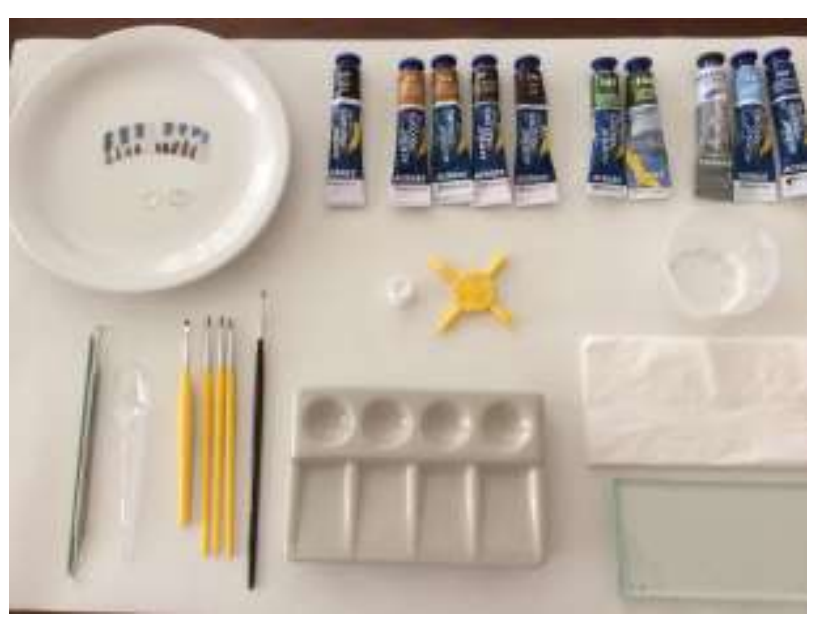

Source: Authors.

After this process of characterization, the sclera was inserted into the muffle and coated with translucent thermopolymerizable acrylic resin. Then it was finished and polished (Figure 8). Thus the ocular prosthesis was installed and the aesthetics and functional movements were evaluated (Figure 9). 
Figure 8. A) Reduction of the scleral curvature. B) Characterization with red silk fibers; C) Final ocular prosthesis.

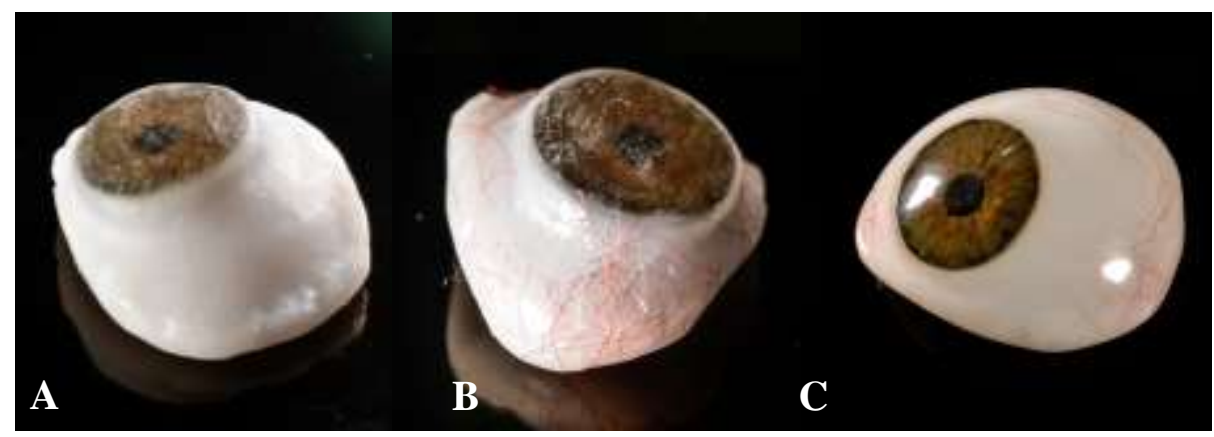

Source: Authors.

Figure 9. Final prosthesis A) Frontal side; B) Anophthalmic socket with the prosthesis.

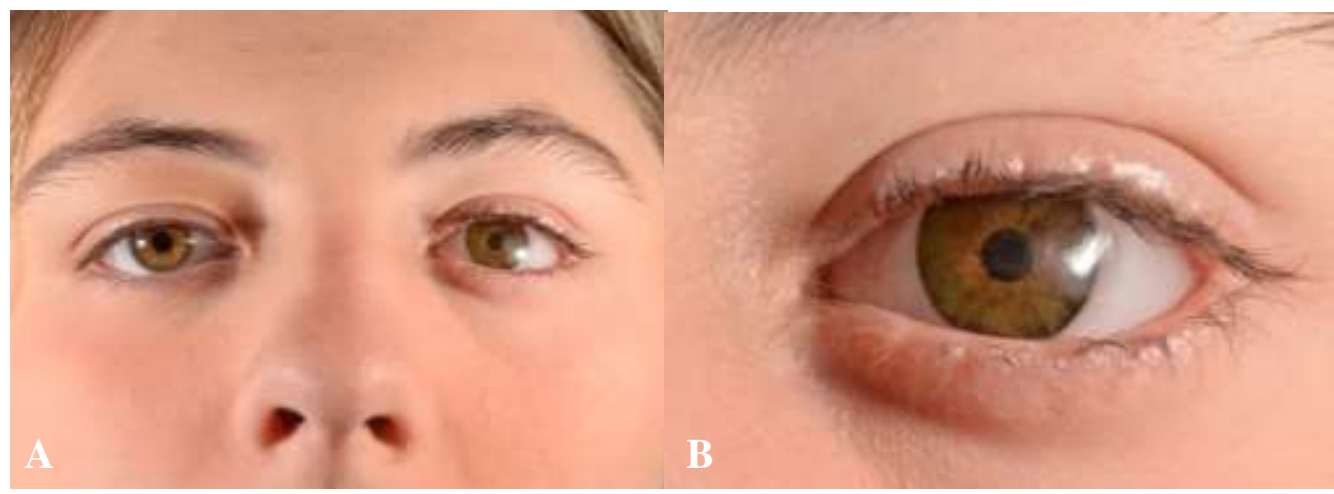

Source: Authors.

The patient was instructed on an insertion and removal technique. With regards to the hygiene procedures, she was instructed to wash her hands with neutral soup, remove the prosthesis from the anophthalmic cavity, apply a drop of soap on the prosthesis surface, rub it with her finger for one minute and rinse under running water; wash and rinse the face with soap, wash the cavity with plenty of water, and then insert the prosthesis into the anophthalmic cavity. In addition, the patient was instructed not to rub their eyes and, if necessary, to drip the saline into the anophtalmic cavity without removing the prothesis. Further follow-up was done after 2 weeks and it was recommended that the patient change the prosthesis once every 2 years.

\section{Results and Discussion}

Different conditions can result in the loss of an eye-ball including congenital defects, irreparable trauma, tumors, painful blind eye, sympathetic ophthalmia or the need for histological confirmation of a suspected diagnosis. In those situations, the replacement of the lost eye should occur promptly in order to promote physical and psychological healing for the patient and to improve social acceptance (Artopoulou, et al., 2006). A multidisciplinary team is fundamental to provide accurate and effective rehabilitation of the patients. Each professional has a certain role depending on the specifications of the clinical condition. Overall, oncologists, ophthalmologists and surgeons are responsible for the diagnosis, treatment planning and surgical procedures. Whereas, the maxillofacial prosthodontists and technician are in charge of the confection of the prosthesis. Therefore, combined efforts along all the phases of the treatment are essential to achieve a long lasting solution for the patient's need (Bartlett \& Moore, 1973). 
An ideal prosthesis must restore the normal opening of the eye, provide eyelid support, be adequately retained and aesthetically pleasing and, if possible, restore a degree of eye mobility (Jamayet, et al., 2013). These conditions can be best achieved when rehabilitation occurs right after the loss of the eye.

In the present study, a new ocular prosthesis was fabricated in a young patient whose former rehabilitation was esthetically and functionally inadequate. Specially in patients during growth periods, the regular change of the prosthesis is mandatory in order to maintain steady contact with the cavity, to give continued stimulus to the socket growth and surrounding tissues (Bartlett \& Moore, 1973). Periodical chances of ocular prosthesis are essential because the constant rate of the facial growth results in a loss of ocular prosthesis adaptation and, as a consequence, the eyelid support reduces.

Ideally, in the early childhood, the prothesis must be elaborated as soon as possible with periodic replacements in accordance with the growing age since the orbital volume increases in a constant rate (Yago \& Furuta, 2001; Anson, et al., 2004; Bentley, et al., 2002). In this particular case, the patient already presented a facial asymmetry probably associated with the fact that she only received an ocular prosthesis ten years after the surgical removal of the eye. Moreover, the first prosthesis was used during a long period without any modifications or replacements.

Unfortunately, the delay in the care occurs more frequent than the ideal situation. The lack of communication between the health providers with each other and with the patient or his/her legal guardian may be one of the reasons that contribute to this event. Besides, still there is misinformation related to this type of treatment, particularly in pediatric cases, since many patients and professionals aren't aware of the necessity of constant prosthesis modifications. Also in some places, there aren't specialized centers or professionals that perform these category of treatment. As a consequence, many patients with unrestored anophthalmic sockets exhibit growth retardation which can lead to facial disfigurement (Agrawal, et al., 2012).

The prosthesis can be pre-fabricated or custom-made. The customized prosthesis presents better functional and aesthetic results because it contributes to a better mobility, pressure distribution and better fit in the anophthalmic cavity (BonaqueGonzález, et al., 2015). These prostheses can be fabricated through a conventional or digital workflow. The association of available technology, such as computer aided design and rapid manufacturing technology, produces more comfortable prosthesis in a lesser time (Alam, et al., 2017). Successful cases of digitally designed and printed iris were described on the literature (Farook, et al., 2019). However, the conventional methods are more accessible and were employed on the present case.

The literature provides several techniques and materials for the fabrication of customized prosthesis (Goiato, et al., 2014; Monkey, et al., 2018; Kulkarni, et al., 2018; Maskey, et al., 2019). Among the materials described, glass and methyl methacrylate resin are the most employed. However, glass isn't the first option as it is fragile and can suffer surface deterioration from contact with orbital fluids (Erpf, 1953). For that reason, nowadays, methyl methacrylate resin is more used because of its superior biocompatibility, aesthetic characteristics, good cleanability, durability, reliable mechanical retention, adaptability of form, low cost and availability (Ogawa \& Hasegawa, 2005).

Different ocular impression techniques have been proposed to provide a precise register of the topography of the eye socket (Patil, et al., 2008; Mathews, et al., 2000). These techniques can be subdivided into different categories, such as: direct or external impression; impression with a stock, modified stock or custom tray; and wax scleral blank technique. The main impression materials are irreversible hydrocolloids and silicones (Raizada \& Rani, 2007) The technique and material choice depending on the operator's ability and preference. In this case, a direct technique using condensation silicone ejected in the cavity with a syringe was used, which provided a precise copy of the ocular defect.

With regard to the fabrication of the sclera pattern, wax or acrylic resin can be used. Due to its properties, such as polishing, the acrylic resin is preferred since it is more comfortable for the patient and also allows better size and contour evaluation (Cevik, et al., 2012). 
An accurate iris reproduction is a critical stage during the fabrication of an ocular prosthesis (Goiato, et al., 2019). Several methods can be used to replicate the natural iris including manual painting, reverse painting using prefabricated caps and use of digital images of the patient's healthy eye (Buzayan, et al., 2015). The manual iris painting technique using acrylic paint in prefabricate caps, as used in this case, has the advantage of providing natural-like characteristics and adequate color stability (Raizada \& Rani, 2007; Fernandes, et al., 2009; Walshaw, et al., 2018). However, it depends on the operator's artistic skills and can be more time-consuming.

Furthermore, the correct positioning of the iris is also important. In order to establish a realism, symmetry and a naturalappearing gaze, it is necessary to guarantee a precise duplication of size and location of the iris. Different technics can be used. In this case, light reflection viewed symmetrically in the natural eye was used as an auxiliar way to visually determine the pupile position. So the patient fixed his gaze on a predetermined object and it was possible to confirm the position compared to the contralateral eye. But the use of auxiliar devices may be helpful to determine the iris orientation. Several tools have been described in the scientific literature, such as: the use of a pupillometer, a plastic strip template, a millimeter rule, an ocular locator and fixed caliper, inverted anatomic tracings, a Boley's gauge, a transparent graph grid, computer simulation approach with optical scanning technique, computer-aided design, a customized scale and also pupillary distance ruler (Bhochhibhoya, et al., 2019; Manvi \& Ghadiali, 2008; Malik, et al., 2014).

The awareness of legal guardians and patients is essential to the success of the treatment in pediatric patients. It is imperative that they recognize the need to rehabilitate the anophthalmic cavity right after the surgical intervention and to constantly replace the ocular prosthesis at most every two years (Bonaque-González, et al., 2015). Furthermore, periodical follow-up appointments are crucial to evaluate the prosthesis, its adaptation to the surrounding tissue, the presence of associated pathologies and the patients' satisfaction.

Several studies have described the success of the early treatment on anophthalmic pediatric patients and confirmed the importance of continual monitoring and constant modification of the ocular prosthesis (Stah, et al., 2015; Santos, et al., 2017; Pavaiya, et al., 2010). These articles concluded that in order to promote an adequate facial development and contribute to the construction of the patient's psychological and social features the prostheses have an utmost importance. Not only that, it is necessary to determine periodical ocular prosthesis changes along the whole period of craniofacial growth to minimize the possible discrepancy between the compromised and the health sides (Agrawal, et al., 2012).

In that manner, ocular rehabilitation will successfully restores the compromised aesthetics, increase the social life and self-esteem of the patient. In addition, these prosthesis maintain the normal physiology of the ocular area since they prevent possible complication such as ulcers, tissue retraction, severe orbital defects, eyebrow and eyelids drooping; restore tear dynamics; and even promote increased electrical activity of orbicularis oculi muscle (Goiato, et al., 2013; Goiato, et al., 2015).

\section{Conclusion}

Rehabilitation of pediatric and teenager patients with an ocular prosthesis is a challenge due to the continuous physical and psychological development during the growth period. Hence, the multidisciplinary team must execute a closer follow-up. The outcome of the present case was considered successful as the patient was satisfied with the aesthetics and comfort of the prosthesis.

\section{Acknowledgments}

The authors would like to acknowledge the patient who participated on the study, her legal responsible and the dental technician whose work was essential to the final result. 


\section{Authors' contributions}

All the authors meet the criteria for authorship: substantial contributions to the conception of the work, drafting of the work, final approval of the version to be published and agreement to be accountable for all aspects of the work. BGC, DZG, LRM and CHLS wrote and critically reviewed this article.

\section{References}

Agrawal, K. K., Mall, P., Alvi, H. A., Rao, J. \& Singh, K. (2012). Fabrication of custom made eye prosthesis for anophthalmic paediatric patients: 2 case reports. Journal of Interdisciplinary Dentistry, 2 (2), 128-131.

Alam, M. S., Sugavaneswaran, M., Arumaikkannu, G. \& Mukherjee, B. (2017). An innovative method of ocular prosthesis fabrication by bio-CAD and rapid 3D printing technology: a pilot study. Orbit, 36 (4), 223-227.

Anson, C., Karl, F., Lawrance, Y. \& Maurice, Y. (2004). Orbital development in Hong Kong Chinese subjects. Ophthalmic Physiol Opt, 24 (5), $436-439$.

Artopoulou, I., Mountgomery, P., Wesly, P. \& Lemon, J.C. (2006). Digital imaging in the fabrication of ocular prosthesis. J Prosthet Dent, 95 (4), $327-330$.

Bartlett, S. O. \& Moore, D. J. (1973). Ocular prosthesis: a physiologic system. J Prosthet Dent, 29 (4), 450-459.

Bentley, R. P., Sgouros, S., Natarajan, K., Dover, M. S. \& Hockley, A. D. (2002). Normal changes in orbital volume during childhood. J Neurosurg, 96 (4), $742-746$.

Bhochhibhoya, A., Mishra, S., Mathema, S., Acharya, B. \& Maskey, B. (2019). Alternative technique of iris orientation in a custom-made ocular prosthesis. Journal of Prosthodontics, 28, 601-604.

Bonaque-González, S., Amigó, A. \& Rodríguez-Luna, C. (2015). Recommendations for post-adaption care of an ocular prosthesis: A review. Cont Lens and Anterior Eye, 38 (6), 397-401.

Buzayan, M. M., Ariffin, Y. T., Yunus, N. \& Mahmood, W. A. A. B. (2015). Ocular defect rehabilitation using photography and digital imaging: a clinical report. Journal of Prosthodontics, 24, 506-510.

Cevik, P., Dilber, E. \& Eraslan, O. (2012). Different techniques in fabrication of ocular prosthesis. J Craniofac Surg, 23 (6), 1779-1781.

Erpf, S. F. (1953). Comparative features of plastic and/or glass in artificial-eye construction. AMA Arch Ophthalmol, 50 (6), 737-744.

Farook, T. H., Jamayet, N. B., Abdullah, J. Y., Rajion, Z. A. \& Alam, M. K. (2019). A systematic review of the computerized tools and digital techniques applied to fabricate nasal, auricular, orbital and ocular prostheses for facial defect rehabilitation. J Stomatol Oral Maxillofac Surg, 121 (3), 268-277.

Fernandes, A. U., Goiato, M. C., Batista, M. A. J. \& Santos, D. M. (2009). Color alteration of the paint used for iris painting in ocular prostheses. Braz Oral Res, 23 (4), 386-392.

Fernandes, A. U., Goiato, M. C. \& Santos, D. M. (2009). Effect of weathering and thickness on the superficial microhardness of acrylic resin and ocular button. Cont Lens Anterior Eye, 32 (6), 283-287.

Goiato, M. C., Pesqueira, A. A., Silva, C. R., Gennari Filho, H. \& Santos, D. M. (2009). Patient satisfaction with maxillofacial prosthesis. Literature review. $J$ Plast Reconstr Aesthet Surg, 62 (2), 175-180.

Goiato, M. C., Santos, D. M., Bannwart, L. C., Moreno, A., Pesqueira, A. A., Haddad, M. F., et al. (2013). Psychosocial impact on anophthalmic patients wearing ocular prosthesis. Int J Oral Maxillofac Surg, 42 (1), 113-119.

Goiato, M. C., Bannwart, L. C., Haddad, M. F., Santos, D. M., Pesqueira, A. A. \& Miyahara, G. I. (2014). Fabrication techniques for ocular prostheses - an overview. Orbit, 33 (3), 229-233.

Goiato, M. C., Santos, M. R., Monteiro, B. C., Moreno, A., Bannwart, L. C., Filho, A. J. V., et al. (2015). Electrical activity of the orbicularis muscles before and after installation of ocular prostheses. Int J Oral Maxillofac Surg, 44 (1), 127-131.

Goiato, M. C., Santos, D. M., Ervolino, I. C. S., Brunetto, J. L., Bertoz, A. P. M. \& Melo Neto, C. L. M. (2019). Prosthetic rehabilitation of an eye globe: case report. Med Arch, 73 (6), 433-435.

Jain, D. C., Hegde, V., Aparna, I. N. \& Dhanasekar, B. (2010). Ocular prosthesis: an esthetic vision. J Nepal Dent Assoc, 11 (1), 101-106.

Jamayet, N. B., Srithavaj, T. \& Alam, M. K. (2010). A complete procedure of ocular prosthesis: Case report. Int Medical J, 20 (6), 729-730.

Kennedy, R. E. (1992). The effect of early enucleation on the orbit in animals and humans. Adv Ophthalmic Plast Reconstr Surg, 9, 1-39.

Kulkarni, R. S., Kulkarni, P., Shah, R. J. \& Tomar, B. (2018). Aesthetically characterized ocular prosthesis. J Coll Physicians Surg Pak, 28 (6), 476-478.

Malik, P., Rathee, M. \& Singh, J. (2014). Ocular defect: a prosthodontic challenge. Int J Dent Sci Res, 5, 120-122.

Manvi, S., \& Ghadiali, B. (2008). Prosthetic rehabilitation of a patient with an orbital defect using a simplified approach. J Ind Prosthodont Soc, 8, 116-118. 
Research, Society and Development, v. 10, n. 10, e287101018692, 2021

(CC BY 4.0) | ISSN 2525-3409 | DOI: http://dx.doi.org/10.33448/rsd-v10i10.18692

Mathews, M. F., Smith, R. M., Sutton, A. J. \& Hudson, R. (2000). The ocular impression: a review of the literature and presentation of an alternate technique. J Prosthodont, 9 (4), 210-216.

Maskey, B., Mathema, S. R. B., Shrestha, K. \& Bhochhibhoya, A. (2019). A simplified approach to fabricate a hollow ocular prosthesis. J Prosthodont, 28 (7), $849-852$.

Monken, L. F., Coelho, L. V., Costa, M. S., Arruda, J. A. A., Mesquita, R. A. \& Moreno, A. (2018). Custom-made ocular prosthesis for atrophic an ophthalmic cavity. J Craniofac Surg, 29 (6), 625-627.

Ogawa, T. \& Hasegawa A. Effect of curing environment on mechanical properties and polymerizing behaviour of methyl-methacrylate autopolymerizing resin. J Oral Rehabil. 2005, 32(3):221-226.

Parr, G. R., Goldman, B. M. \& Rahn, A. O. (1983). Surgical considerations in the prosthetic treatment of ocular and orbital defects. J Prosthet Dent, 49 (3), $379-385$.

Patil, S. B., Meshramkar, R., Naveen, B. H. \& Patil, N. P. (2008). Ocular prosthesis: a brief review and fabrication of an ocular prosthesis for a geriatric patient. Gerodontology, 25 (1), 57-62.

Pavaiya, A., Singh, V. S., Chand, P. \& Singh, D. R. (2010). Fabrication of an ocular prosthesis for a pediatric retinoblastoma patient by a simplified technique. Int J Clin Pediatr Dent, 3 (2), 97-99.

Raizada, K. \& Rani, D. (2007). Ocular prosthesis. Cont Lens Anterior Eye, 30 (3), 152-162.

Raizada. D., Raizada, K., Naik, M., Murthy, R., Bhaduri, A. \& Honavar, S. G. (2011). Custom Ocular Prosthesis in Children: How Often is a Change Required? Orbit, 30 (5), 208-213.

Santos, D. M., Andreotti, A. M., Iyda, B. G., Dekon, S. F. C. \& Goiato, M. C. (2017). Expander eye prosthesis assisting ocular rehabilitation in child with eye loss. Journal of Clinical and Diagnostic Research, 11 (8), 6-8.

Stah, V., Yadav, L., Singh, M. \& Kharbanda, S. (2015). Custom ocular prosthesis in rehabilitation of a child operated for retinoblastoma. National Journal of Maxillofacial Surgery, 6, 232-236.

Walshaw, E., Zoltie, T., Bartlett, P. \& Gout, T. (2018). Manufacture of high definition ocular prosthesis. Br J Oral Maxillofac Surg, 56 (9), $893-894$.

Yago, K. \& Furuta, M. (2001). Orbital growth after unilateral enucleation in infancy without an orbital implant. Jpn J Ophthalmol, 45 (6), 648-652. 